\title{
SPECIAL ISSUE OF
}

\section{SEED SCIENCE RESEARCH}

The June 1994 issue of the journal will contain papers presented at the International Workshop, Desiccation Tolerance and Sensitivity of Seeds and Vegetative Plant Tissues held in the Kruger National Park, South Africa from January 17th to 22nd, 1994

\section{Topics to be covered include the following:}

Desiccation tolerance and DNA, proteins, abscisic acid, lipids or sugars

Effects of desiccation on dormancy, recalcitrance and storage

Limits of desiccation tolerance

Structure and evolutionary aspects of recalcitrance

Implications of free radicals in recalcitrant seeds

Extra copıes of this 1ssue are avallable separately at $£ 45 / \mathrm{US} \$ 70$

Orders, or requests for more information should be sent to Lorraine Rogers Marketıng \& Distribution Services CAB INTERNATIONAL Wallıngford, Oxon OX10 8DE, UK Tel (0491) 832111, Fax (0491) 826090 CAB INTERNATIONAL 


\title{
PEAS: GENETICS, MOLECULAR BIOLOGY AND BIOTECHNOLOGY
}

\author{
Edited by R Casey and D R Davies, John Innes Institute, Norwıch, UK \\ Biotechnology in Agriculture Series, 10
}

Our knowledge of the molecular biology and genetics of peas, particularly in the fields of storage product biology, genetic mapping, transformation, plant development and the rhizobium symbiosis, has increased dramatically in recent years The pea is also a model plant for research on a number of topics including starch biosynthesis and gene regulation by light This book contains a number of reviews on progress in various aspects of pea molecular genetics It places them in perspective for those concerned with the breeding, agronomy and exploitation of peas and will also be of value to those working on other grain legumes It is also an important volume for research workers and advanced students in many areas of plant sciences, especially plant genetics and biotechnology

\section{Contents}

- The pea crop, $D R$ Davies

- The nuclear genome, TH N Ellis

- The plastid genome, TH N Ellis

- Regulation of gene expression, PM Gilmartin

- Genetic and developmental analysis of the seed, TL Wang and C L Hedley

- Biochemistry and molecular biology of seed products, $R$ Casey, C A M Domoney and $A M$ Smith

- Developmental mutants, I C Murfet and J B Rezd

- Molecular approaches to the study of diseases of peas, A Vivian

- Root nodules, rhizobium and nitrogen fixation, $N J$ Brewin, $M J$ Ambrose and J A Downie

- Tissue culture and transformation, $D R$ Davies and P M Mullineaux

- Opportunities in relation to developments in plant biotechnology, $D R$ Daves

December $1993 \quad 336$ pages HB ISBN 08591988636

Price $£ 4995$ (US\$95 00 Americas only) 


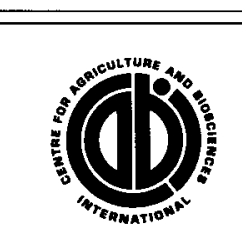

CAB INTERNATIONAL

\section{CROPCD}

- 20 years of information

- over $\mathbf{4 0 0 , 0 0 0}$ references

- worldwide coverage

- subject-specific data

All so easily accessible at the touch of a button for anyone interested in the biology, production and management of field crops, fodder crops and grasslands.

CROPCD, one of several new CD-ROM products from CAB INTERNATIONAL, has just been released. All that is required to access this remarkable archive of research information is a personal computer with CD-ROM drive attached.

For further details or to request a 30-day FREE TRIAL please contact the Marketing Executive for CD-ROM, CAB INTERNATIONAL, Wallingford, Oxon OX10 8DE, UK. 


\title{
FIFTH INTERNATIONAL WORKSHOP ON SEEDS
}

\author{
Basic and Applied Aspects of Seed Biology \\ University of Reading, UK
}

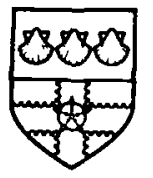

11 - 15 September 1995

\section{First Circular: Preliminary Registration}

The fifth meeting in the series of International Workshops which began in Israel in 1979 (contınuing at Wageningen in 1985, Willamsburg in 1989, Angers in 1992) will be held at the University of Readıng, UK, between Monday 11 and Friday 15 September 1995 Reading lies 40 miles west of London, 30 minutes by train London's international airports at Heathrow and Gatwick have direct bus and train connections to Reading

I am pleased to invite you to the meeting Please complete the form below if you wish to receive the second curcular providing detalls of the meeting and how to book

accommodation, etc Your prompt return of this form to me at the address shown below will enable me to better gauge the demand for accommodation, and also to determine the themes of the scientific programme Please copy this form to interested colleagues

I look forward to receiving your reply

Richard Ellis (1995 Conference),

Department of Agnculture, Unuversity of Reading,

Earley Gate, P O Box 236,

Reading RG6 2AT, UK

\section{FIFTH INTERNATIONAL WORKSHOP ON SEEDS, READING 1995 Prelıminary Registration}

NAME (Mr/Ms/Mrs/Dr/Prof)

\section{ADDRESS}

I am interested in presenting a paper/poster* on (please give subject area or list keywords)

I would prefer accommodation in a medium-grade hotel (about $£ 70$ per night, including breakfast)/a university hall of residence (from $£ 30$ to $£ 45$ per night, including meals)* *please delete as appropriate 


\section{(6)) \\ CAB INTERNATIONAL \\ The Molecular Biology of Flowering}

\section{Edited by B. R. Jordan, Horticulture Research International, Littlehampton, UK}

The transition from vegetative to reproductive growth is one of the most important developmental changes in plants Although the physiology of the process has been well documented, the molecular basis has only recently begun to be determined This book reviews our current knowledge of the molecular biology and genetics of flowering, a subject that is rapidly being recognized for both its fundamental importance and its biotechnological exploitation. It will interest research workers and advanced students in plant genetics and plant molecular biology

July 1993272 pages $\mathrm{HB}$

ISBN 0851987230

Price $£ 4500$ (US $\$ 8550$ Americas only)

To order, please contact

CAB INTERNATIONAL

Wallıngford, Oxon, OX10 8DE, UK

Tel (0491) 832111 Fax (0491) 826090 


\section{Seed Science Research}

\section{Research Papers}

Bradford, K. J. \& Somasco, O. A. Water relations of lettuce seed thermoinhibition. I. Priming and endosperm effects on base water potential

Dutta, S. \& Bradford, K. J. Water relations of lettuce seed thermoinhibition. II. Ethylene and endosperm effects on base water potential

Kristie, D. N. \& Fielding, A. Influence of temperature on the Pfr level required for germination in lettuce cv. Grand Rapids

Maki, K. S., Bartsch, J. A., Pitt, R. E. \& Leopold A. C. Viscoelastic properties and the glassy state in soybeans.

Shatters, R. G., Jr., Abdelghany, A., Elbagoury, O. \& West, S. H. Soybean seed deterioration and response to osmotic priming: changes in specific enzyme activities in extracts from dry and germinating seeds

Vázquez-Ramos, J. M. \& Martinez, G. A partial purification and characterization of organellar DNA polymerases in germinating maize.

Zhang, M., Maeda, Y., Furihata, Y., Nakamaru, Y. \& Esashi, Y. A mechanism of seed deterioration in relation to the volatile compounds evolved by dry seeds themselves

\section{Abstracted in Seed Abstracts (CAB ABSTRACTS),}

Current Advances in Plant Science and BIOSIS

C CAB INTERNATIONAL, 1994

All rights reserved. No part of this publication may be reproduced, in any form or by any means, electronically, mechanically, by photocopying, recording or otherwise. without prior permission of the copyright owner. 